\title{
Coastal Nutrition Status of the Country Reviewed from Social Culture and Islamic Perspective
}

\author{
${ }^{1}$ Eliska, ${ }^{2}$ Nurhayati, ${ }^{3}$ Petti Siti Fatimah \\ ${ }^{1}$ Faculty of Public Health, State Islamic University Of North Sumatra \\ Coresponding author: Eliska, e-mail : eliska@uinsu.ac.id \\ Co-Author : NN : nurhayati@uinsu.ac.id, PSF : petti.siti.fatimah@gmail.com \\ Submitted: 16/09/2020 Revised: 02/10/2020 Accepted: 19/10/2020 Published online: 21/10/2020
}

doi: https://doi.org/10.35308/j-kesmas.v7i2.1732 How to cite this article: Eliska, E., Nurhayati, N., \& Fatimah, P.S. (2020). Coastal Nutrition Status of the Country Reviewed From Social Culture and Islamic Perspective. J-Kesmas: Jurnal Fakultas Kesehatan Masyarakat (The Indonesian Journal of Public Health), 7(2), 79-82.

\begin{abstract}
Coastal communities are people who live and carry out socio-economic activities that depend on coastal resources, one of which is fishermen. The cultural identity of coastal communities as a whole is formed from the culture of fishermen who are directly related to the management of coastal and marine resources. Nutritional problems arise not only from health problems but also influenced by social culture and religion. The design of this study uses quantitative research with a Cross Sectional.The sample is the total population selected by the purposive sampling method, which is 71 students from five schools. The instrument in this study used a questionnaire. Techniques and data processing are carried out by using a computer program to present data in the form of frequency and then the results are presented in the table. It is known that there is a relationship between nutritional status and socio-culture in coastal communities because the nutritional status of school-age children is below the threshold of $25.4 \%$, and $12.7 \%$ is very thin.This happens because most parents of students have daily work as fishermen so that the lack of income from parents causes children's nutritional intake to decrease, while seen from the cultural tribes of the coastal community there are more Javanese tribes which result in low nutritional status due to lack of variety in food intake.
\end{abstract}

Keywords: Nutritional Status, Coastal Area, Social Culture, Islamic Perspective.

\section{Introduction}

Indonesia is one of the largest archipelagic countries in the world. Coastal communities are people who live and carry out socio-economic activities related to coastal resources. As a coastal area in the activities of the population utilizing marine resources as a livelihood, especially for coastal communities.

Health problems are not only the main cause of the emergence of nutritional problems, but the poverty factor is a major factor in nutritional problems. Nutritional problems occur mainly in developing countries in school-age children (6-12 years).

One of the problems faced by elementary school children is the low level of health and nutritional status, this is related to the low level of food consumption or imbalance in consumption of nutrients and nutritional adequacy of these children.

Nutritional deficiencies in food, including breakfast, can cause growth disorders, especially physical growth, which can be seen from a short, fat or thin body size. Children are one of the nation's development assets in the future because it is important to pay attention to food intake so that nutrition growth and mental development of children run optimally and make quality children.

Based on observations of 71 students in elementary schools in coastal areas it was found that 44 people $(62 \%)$ had normal nutritional status, were very thin as many as 18 people $(25.4 \%)$ and 9 people $(12.7 \%)$ were very thin. In the survey, it was known that the students did not have breakfast as many as 22 people $(31 \%)$ and those who ate breakfast were 49 people $(69 \%)$. Seen from the tribe as many as 25 people $(35.2 \%)$ are Javanese tribes known when interviewing they chose to eat in a simple manner with not much variety of side dishes, so this also caused the existence of children with low nutritional status.

\section{Materials and Methods}

The design of this study uses quantitative research with a Cross, data collection is done once or at the time of research, without having to look at the background or past or future events. The sample is the 
total population selected by the purposive sampling method. The instrument in this study used a questionnaire. Techniques and data processing are carried out by using a computer program to present data in the form of frequency and then the results are presented in the table.

\section{Results}

This research was conducted on school-age children in the coastal area of PercutSei Tuan, with a total sample of 71 people to see their nutritional status. Individual characteristics are reviewed based on gender, ethnicity, and parental salary.

The results showed that socio-culture was gender, the majority of respondents were female as many as 49 people $(69.0 \%)$, the majority of the tribe were Javanese as many as 25 people $(35.2 \%)$, the salary of respondents was Low $(<$ Rp. 2.000.000) 61 people $(85.9 \%)$. Based on breakfast habits, the majority of respondents had breakfast habits as many as 49 people $(69.0 \%)$.

Distribution of nutritional status measured by anthropometric measurements with the nutritional status of the most respondents was normal as many as 44 people $(62.0 \%)$, after that thin were 18 people $(25.4 \%)$ and very thin as many as 9 people $(12.7 \%)$.

Relationship between socio-culture and nutritional status of respondents was done by Chi Square test. The results of the study using the chi square test, for the tribal variables indicate that there is a relationship between the tribe and the nutritional status of children in the coastal area $(\mathrm{p}=0.034)$. Income variable shows that there is a relationship between income and nutritional status of children (p $=0.028$ ). As for the breakfast breakfast habits variable, it shows that there is a significant relationship between the breakfast habits of children with nutritional status with a value of $p=0,000$.

\section{Discussion}

\section{Children's Nutritional Status Viewed from Socio-Culture}

The results of the study using the chi square test, for the tribal variables indicate that there is a relationship between the tribe and the nutritional status of children in the coastal area $(\mathrm{p}=0.034)$. Based on the results of the research, the majority of the people living in this coastal area are Javanese as many as 25 people (35.2\%), followed by the tribes of Malay, Padang, Mandailing and Aceh.
The results of the study showed that the respondents' income was low. This is because most of the work of the respondent's parents is fishermen, whose income depends on the fish caught. Chi Square test results show that there is a relationship between income and nutritional status of children $(\mathrm{p}=0.028)$.

Coastal communities in general have the characteristics of being mostly mediocre income, classified as poor due to natural factors, which are solely dependent on seasonal catches, low income, inadequate household availability, minimal education for children. This is because the fishing community does not have careful planning for the education of their children. Education for most coastal communities is still a number requirement in the household, it can be said that enthusiasm for education in fishing communities is relatively low.

Breakfast habits, showed there was a significant relationship between the breakfast habits of children with nutritional status with a value of $p=0,000$. The results showed that the majority of respondents had a breakfast habit that was as many as 49 people $(69.0 \%)$, but the breakfast breakfast menu of respondents in general was of low nutritional quality.

Nutritional status is defined as a state of health of a person's body or group of people caused by consumption, absorption and use of food nutrients. There are two factors that influence the growth and nutritional status of children in developing countries, namely infectious diseases and consumption of foods that do not meet nutritional needs. School children in developing countries generally suffer from short-term hunger, lack of protein energy, and lack of iodine, vitamin A and iron. This problem arises because at this age are very active playing and many activities both at school and in their home environment.

Food consumption behavior is one of the factors influencing the human development index. Fulfillment of sufficient energy sources, building materials and nutritional status of a person is obtained from the pattern of food consumed every day.

\section{Child Nutrition in an Islamic Perspective}

Islam is a religion that is rahmatanlilaminalamin is a religion that is very concerned about food consumed by children, including when it is still in the womb and is an important study in Islam because it is related to human values. 
Healthy food is a food that meets balanced and adequate nutritional standards. Proportional food is food that is eaten according to the needs of eaters, not reduced and not excessive. As the Qur'an tells mothers to breastfeed their children with breast milk (ASI) and set an ideal time period for weaning it, as the word of God in surah AlBaqarah verse 233 which means: "And mothers should breastfeed their children for two years full, for those who want to breastfeed perfectly". While safe food is food that does not bring a source of disease.

Islam teaches that one of the obligations or necessity of parents to children is to maintain the survival of children and their development by providing them with sufficient income. Children will grow normally and healthy if the nutritional intake provided is fulfilled. Underestimating or abandoning these obligations is one of the great sins. As said by the Prophet, which means: "Enough someone is guilty if he wastes the person who is under the responsibility (his income)."(Narrated by Abu Dawud). One of the living needs of the child that parents must provide is including providing nutritious food to children.

\section{Conclusion}

Based on the description above, it is known that there is a relationship between nutritional status and socio-culture in coastal communities because the nutritional status of school-aged children is below the threshold of $25.4 \%$ thin and $12.7 \%$ very thin. This happens because most parents have daily work as fishermen so that the lack of income from parents causes children's nutritional intake to decrease which then affects their growth, development and health.Besides that, it can be seen from the cultural tribes of the coastal communities that there are more Javanese tribes which result in low nutritional status due to lack of diverse food intake. Whereas from an Islamic perspective it is clear in the Qur'an that every human being is encouraged to pay attention to the food to be consumed in order to avoid health problems and pay attention to daily nutritional intake for human survival.

\section{Acknowledgement}

This research was carried out well because of help from other parties.

\section{Author Contribution and Competing Interest}

All of the authors contributed in collecting and analyzing the data, including preparing the manuscript. The author assures thet there is no conflict of interest in the activities and preparation of this report.

\section{Publisher's Note}

J-Kesmas: Jurnal Fakultas Kesehatan Masyarakat (Indonesia Journal of Public Health) remains neutral with regard to jurisdictional claims in published institutional affiliation.

\section{References}

Bunga Astria Paramashanti. (2019). Gizi Bagi Ibu \& Anak. Yogyakarta : Pustaka Baru.

Departemen Agama RI. (2006). Al-Quran dan Terjemahnya. Surabaya : Pustaka Agung Harapan.

Ferriawan, T. (2017). Analisis Gizi Seimbang Pada Masyarakat Pesisir Pantai Selat Madura Desa Kalanganyar Kecamatan Sedati Kabupaten Sidoarjo. Jurnal Tata Boga, 5(3), 28-33.

Gamal K. (2012) Sakit dan Pengobatan Secara Islami. Lihat juga Zaenal Abidin, "Keluarga Sehat dalam Perspektif Islam”, dalam Jurnal Komunika, 6(1), 1-14

Gibson RS. (2005). Principle of Nutritional Assessment. Oxford University Press, USA.

Hardinsyah, H., \& Aries, M. (2012). Jenis Pangan Sarapan Dan Perannya Dalam Asupan Gizi Harian Anak Usia 6 -12 Tahun Di Indonesia, Jurnal Gizi dan Pangan, 7(2), 89-96.

HM. Budiyanto. (2014). "Hak-Hak Anak Dalam Perspektif Islam". Jurnal Studi Gender dan Anak, 1(1), 32-39.

Khomsan, A. (2010). Pangan dan Gizi Untuk Kesehatan. Jakarta : PT. Raja Grafindo Persada.

Kusnadi. (2007). Jaminan Sosial Nelayan. Yogyakarta : LKiS Pelangi Aksara

Mitayani dan Sartika, W. (2010). Buku Saku Ilmu Gizi. Jakarta: Trans Info Media.

Shihab, M. Q. (1996) Wawasan Al-Quran: Tafsir Maudhu'i atas Pelbagai Persoalan Umat. Bandung: Mizan, 37-148. 
Notoatmodjo. (2007). Promosi Kesehatan dan Ilmu Perilaku. Jakarta (ID) : Rineka Cipta.

Perdana, F., \& Hardinsyah. (2013). Analisis Jenis, Jumlah dan Mutu Gizi Konsumsi Sarapan Anak Indonesia. Jurnal gizi dan Pangan, 8(1), $39-46$.

Trisia. (2010). Kontribusi Sosial Budaya Penyebab Malnutrisi Pada Balita Di Keluarga Nelayan
Skripsi. Jurusan Sosiologi. Fakultas Ilmu sosial dan Perilaku. Universitas Lampung.

Ningsih, Y.A., Suyanto, \& Restuastuti, T. (2016). Gambaran status Gizi pada Siswa Sekolah Dasar Kecamatan Rangsang Kabupaten Kepulauan Meranti. JOM FK, 3(2), 1-12. 